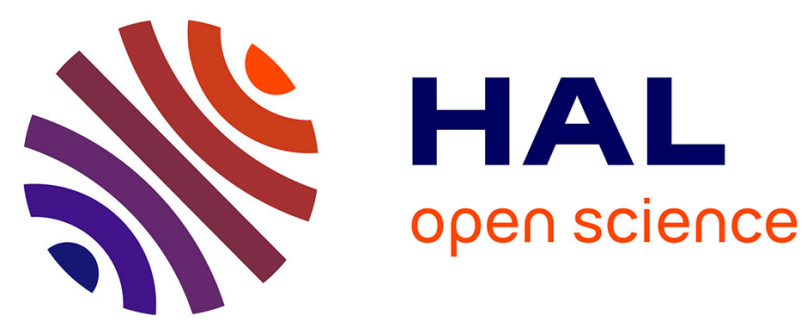

\title{
Laser induced densification of cerium gadolinium oxide: application to single-chamber solid oxide fuel cells
}

\author{
Mariana Mariño, Mathilde Rieu, Jean-Paul Viricelle, Florence Garrelie
}

\section{To cite this version:}

Mariana Mariño, Mathilde Rieu, Jean-Paul Viricelle, Florence Garrelie. Laser induced densification of cerium gadolinium oxide: application to single-chamber solid oxide fuel cells. Applied Surface Science, 2016, 374, pp.370-374. 10.1016/j.apsusc.2015.12.220 . hal-01250246

\section{HAL Id: hal-01250246 \\ https://hal.science/hal-01250246}

Submitted on 24 Jun 2016

HAL is a multi-disciplinary open access archive for the deposit and dissemination of scientific research documents, whether they are published or not. The documents may come from teaching and research institutions in France or abroad, or from public or private research centers.
L'archive ouverte pluridisciplinaire HAL, est destinée au dépôt et à la diffusion de documents scientifiques de niveau recherche, publiés ou non, émanant des établissements d'enseignement et de recherche français ou étrangers, des laboratoires publics ou privés. 


\title{
Laser induced densification of cerium gadolinium oxide: application to single-chamber solid oxide fuel cells
}

\author{
Mariana Mariño ${ }^{a}$, Mathilde Rieu $^{a}$, Jean-Paul Viricelle ${ }^{a}$, Florence Garrelie ${ }^{b}$ \\ a École Nationale Supérieure des Mines, SPIN-EMSE, PRESSIC Department, CNRS:UMR5307, \\ LGF, F-42023 Saint-Étienne, France \\ 'b Université Jean Monnet, Laboratoire Hubert Curien, CNRS: UMR 5516, 42000 Saint-Etienne, \\ France
}

\section{Corresponding author}

Mathilde Rieu: rieu@emse.fr, Tel.: +33 477420282

\begin{abstract}
In single-chamber solid oxide fuel cells (SC-SOFC), anode and cathode are placed in a gas chamber where they are exposed to a fuel/air mixture. Similarly to conventional dual-chamber SOFC, the anode and the cathode are separated by an electrolyte. However, as in the SCSOFC configuration the electrolyte does not play tightness role between compartments, this one can be a porous layer. Nevertheless, it is necessary to have a diffusion barrier to prevent the transportation of hydrogen produced locally at the anode to the cathode that reduces fuel cell performances. This study aims to obtain directly a diffusion barrier through the surface densification of the electrolyte $\mathrm{Ce}_{0.9} \mathrm{Gd}_{0.1} \mathrm{O}_{1.95}$ (CGO) by a laser treatment. $\mathrm{KrF}$ excimer laser and $\mathrm{Yb}$ fiber laser irradiations were used at different fluences and number of pulses to modify the density of the electrolyte coating. Microstructural characterizations confirmed the modifications on the surface of the electrolyte for appropriate experimental conditions showing either grain growth or densified but cracked surfaces. Gas permeation and electrical conductivities of the modified electrolyte were evaluated. Finally SC-SOFC performances were improved for the cells presenting grain growth at the electrolyte surface.
\end{abstract}




\section{Introduction}

Conventional Solid Oxide Fuel Cells (SOFC) are composed of two chambers separated by a dense electrolyte. The difference in oxygen partial pressure between the two separated electrode compartments leads to the establishment of an open circuit voltage (OCV). Contrary to conventional cells, in Single Chamber SOFC (SC-SOFC), the cell is located in a single gas chamber where it is exposed to a gas mixture of fuel and oxidant (air). The working principle is based on the selectivity of the electrodes; the anode must be selective and active for fuel oxidation, whereas the cathode must be selective for reduction of oxygen. Hydrocarbons are generally used to decrease the risk of explosion; hydrogen is therefore obtained by the partial oxidation of the hydrocarbons. Methane was chosen for this study, the most common fuel used in SC-SOFC. Principal reactions are described in reactions 1, 2 and 3 [1].

$$
\begin{aligned}
& \left.\mathrm{CH}_{4}+1 / 2 \mathrm{O}_{2} \rightarrow \mathrm{CO}+2 \mathrm{H}_{2} \text { (reaction } 1\right) \\
& \left.\mathrm{H}_{2}+\mathrm{O}^{2-} \rightarrow \mathrm{H}_{2} \mathrm{O}+2 e^{-} \text {(reaction } 2\right) \\
& \left.\mathrm{CO}+\mathrm{O}^{2-} \rightarrow \mathrm{CO}_{2}+2 e^{-} \text {(reaction } 3\right)
\end{aligned}
$$

As the generation of the OCV depends only on the electrocatalytic activity and selectivity of the electrodes, and not on a dense electrolyte as in conventional SOFC, it is possible to operate without a gastight electrolyte $[1,2]$. This fact allows to use simple and conventional processing methods to prepare the electrolyte. For example, screen-printing, a simple and low-cost deposition technique can be used to prepare a thin and porous layer, because in such a case a dense electrolyte is not required [2-4]. However, some authors [2,3] have indicated that the porosity related to the electrolyte may allow the transport of the hydrogen produced locally at the anode (reaction 1) to the cathode, which can generate an OCV drop and a decrease of cell performances. To prevent hydrogen transportation, it is thus necessary to have a dense electrolyte or at least a diffusion barrier layer but at the same time preserving the porosity of the electrodes.

Solid oxide electrolytes based on cerium gadolinium oxide (CGO) materials are considered to be the most promising candidate materials for use in single-chamber solid oxide fuel cells, because they offer considerably high ionic conductivity at intermediate operating temperatures (450-700 $\left.{ }^{\circ} \mathrm{C}\right)$. Moreover as SC-SOFC operates in hydrocarbon/air mixture and not in pure hydrogen, CGO stability is not a problem [5,6]. Nevertheless, the achievement of full density materials requires sintering temperatures above $1400^{\circ} \mathrm{C}$ [7-9]. Various techniques have been used to densify a CGO electrolyte at $1400^{\circ} \mathrm{C}$; however in the configuration of anode supported SC-SOFC selected in this study, it is difficult to achieve a dense electrolyte deposited by screen-printing by conventional thermal annealing techniques maintaining porous electrodes.

By laser treatment it is possible to induce modifications on materials with localized thermal annealing at high temperatures minimizing heating of the underlying substrate $[10,11]$. Lasers have been employed successfully to treat ceramic materials with an increasing interest in their densification [12-18]. Most of researches are about carbide, bromides and refractory ceramics densification, showing most of the time positive results with continuous lasers $[12,15,19]$. However, it has been demonstrated that pulsed laser irradiation offers an attractive alternative to conventional thermal annealing to oxides densifications [17,18]. Sandu et al. [17] have densified and crystallized $\mathrm{SnO}_{2}: \mathrm{Sb}$ sol-gel films using excimer laser annealing. Tsagarakis et al. [18] have also used an excimer laser to obtain nanocristallized $\mathrm{BaTiO}_{3}$. The high intensity of pulsed laser may induce high heating rates and well-defined localization of the energy input within the irradiated material [20]. 
This study aims to obtain a diffusion barrier of the CGO electrolyte. For this, laser treatments are proposed onto the CGO surface. The influence of laser parameters (wavelength, fluence and number of pulses) has been examined on the laser induced densification of the electrolyte. Microstructural characterizations, permeation tests, electrochemical measurements and fuel cell characterizations were used to determine the effects of laser parameters.

\section{Experimental procedure}

All the materials used for the cells preparation were commercial powders acquired from Fuel Cell Materials. The experimental procedure used to prepare the SC-SOFC was previously described [3]. Anode support was prepared by uniaxial pressing at $250 \mathrm{MPa}$ to obtain a sample of $22 \mathrm{~mm}$ in diameter. The powder mixture was composed of $\mathrm{NiO}(60 \mathrm{wt} \%)$ and CGO (40 wt\%). CGO refers to $\mathrm{Ce}_{0.9} \mathrm{Gd}_{0.1} \mathrm{O}_{1.95}$ composition. Then, the electrolyte was deposited by screen printing. The ink was prepared by mixing $63 \mathrm{wt} \%$ of CGO powder and $33 w t \%$ of a binder $\left(\mathrm{ESL}^{\mathrm{TM}}\right.$ V400). 8 drops per gram of powder of a solvent was added (ESL T404). Two layers of electrolyte ink were deposited with a drying step at $120^{\circ} \mathrm{C}$ for each layer, providing a porous electrolyte around $20 \mu \mathrm{m}$ thick. The assembly was annealed at $120{ }^{\circ} \mathrm{C}$ during $3 \mathrm{~h}$. Finally, surface of the electrolyte was irradiated by the laser.

Two types of pulsed laser were used: a KrF Lambda Physics $(\lambda=248 \mathrm{~nm}, \tau=20 \mathrm{~ns}$, frequency $=$ $10 \mathrm{~Hz}, 4 \times 2.5 \mathrm{~mm}$ laser spot size) and an ytterbium doped fiber YLIA M20EG ( $\lambda=1064 \mathrm{~nm}, \tau=$ $100 \mathrm{~ns}$, frequency $=25 \mathrm{kHz}, 190 \mu \mathrm{m}$ diameter of laser spot size). The laser processing of the overall electrolyte surfaces was carried out with the assistance of linear stages. Overlapping of the successive laser spots was used to ensure the treatment of the whole surface. Irradiations of the electrolyte surface were performed in air, with series of pulses between 1 and $10^{4}$ at various fluences. The experimental processing conditions are summarized in Table 1. The surface microstructure was studied by scanning electron microscopy (FEG-SEM, Jeol JSM 6500 F).

A permeation test was developed to measure gas permeation through CGO layer. The device (Fig. 1 (a)) consists of two cavities where the sample is placed in between. A flow rate of $10 \mathrm{~L} \mathrm{~h}^{-1}$ of helium was sent to the lower cavity. This gas was chosen to simulate hydrogen diffusion through the electrolyte. Same flow rate of nitrogen was simultaneously sent to the upper cavity. Helium percentage which passes through the electrolyte is recovered at the nitrogen outlet and analyzed by gas chromatography (SRA instruments).

a)

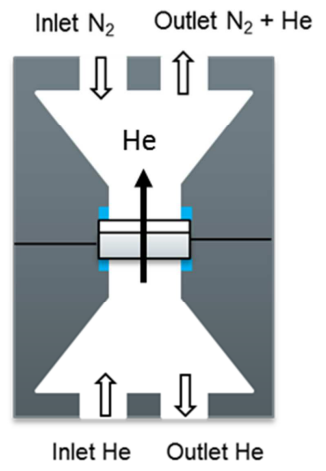

b)

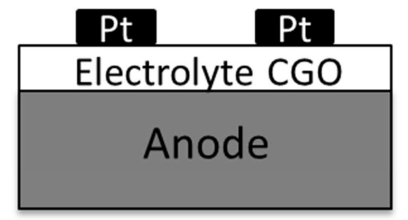

Fig.1. a) Permeation test device, b) Schematic of electrodes configuration for electrical conductivity measurements. 
The electrical conductivity of the electrolytes as a function of temperature was measured by electrochemical impedance spectroscopy (EIS). Two parallel platinum electrodes were deposited on the surface of the electrolyte by screen-printing to create a coplanar configuration (Fig. 1 (b)). Measurements were made in air between $400^{\circ} \mathrm{C}$ and $800^{\circ} \mathrm{C}$ with an impedance meter VersaSTAT3. Frequency range was from $1 \mathrm{MHz}$ to $10 \mathrm{mHz}$ with a voltage amplitude of 50 $\mathrm{mV}$.

Finally, in order to complete SC-SOFC preparation, two layers of cathode material were deposited on the electrolyte surface by screen printing. Ink was composed by $70 \mathrm{wt} \%$ LSCF and $30 \mathrm{wt} \% \mathrm{CGO}$. The cell was annealed at $1100^{\circ} \mathrm{C}$ during $3 \mathrm{~h}$, and finally a gold mesh was screenprinted on the top of the cathode as a current collector. A commercial ink was used (ESL 8880$\mathrm{H})$ and it was annealed at $850^{\circ} \mathrm{C}$ during 1 hour to complete the cell.

The experimental setup for fuel cells characterization was the same as the one used by Rembelski et al. [3]. Fuel cells tests were performed in a quartz tube where a mixture of methane and oxygen flows. The cell was placed into an alumina support between two gold meshes and the gas mixture flows on both sides of the cell. A tubular furnace allowed testing the cells at different temperatures. The electrical measurements were performed using a source measurement unit (Keithley 2400).

Before each cell measurement, anode reduction procedure in nitrogen atmosphere with $10 \%$ of methane $\left(\mathrm{CH}_{4}\right)$ was applied at $600{ }^{\circ} \mathrm{C}$ [3]. Then, cells were tested into a mixture of gas composed of methane and oxygen with a flow rate of $30 \mathrm{~L} \mathrm{~h}^{-1}$. The mixture ratio methane/oxygen $\left(R_{\text {mix }}\right)$ was varied from 0.67 to 2 , with oxygen content fixed at $10 \%$ in order to avoid inflammability mixture. Various temperatures were tested between $400{ }^{\circ} \mathrm{C}$ and $600{ }^{\circ} \mathrm{C}$.

\section{Results and discussion}

\subsection{Microstructural characterization of CGO irradiated surface}

The laser treatment induced noticeable changes on the surface of the $1200^{\circ} \mathrm{C}$ pre-sintered samples. Fig. 2 shows SEM micrographs of different induced laser modifications (Fig. 2 (b-d)) and reference surface sample without laser treatment (Fig. 2 (a)). The surface treated by UV laser presents two different effects. Low laser fluence with a high number of pulses exhibits the beginning of the sintering process (Fig. 2.b). The grain growth on the surface of CGO is evident relative to the surface without laser treatment (Fig. 2.a). Higher laser fluences with low number of pulse using the UV laser show densification effects on the surface (Fig 2.c). However, multiple cracks were observed on the whole surface. These cracks could affect the diffusion barrier layer. At high fluences, top area of the porous layer reached higher temperatures that reduce only the volume of the top area, but not of the remaining supporting area. Different thermal dilatation between treated surface and not treated support produces thermal stresses which can generate the cracks[14,21]. At low laser fluences and low number of pulses, modifications were not visible on the surface.

A similar densification with presence of cracks has been observed in all the samples treated by IR laser with fluences between 2 and $3.6 \mathrm{~J} \mathrm{~cm}^{-2}$ and number of pulses between 5 and 10 . However, as observed in Figure 2.d, the number of cracks is more important relatively to the surface treated by UV laser (Fig.2.c). The different effects, evidenced by SEM observations, are summarized in Table 1. 

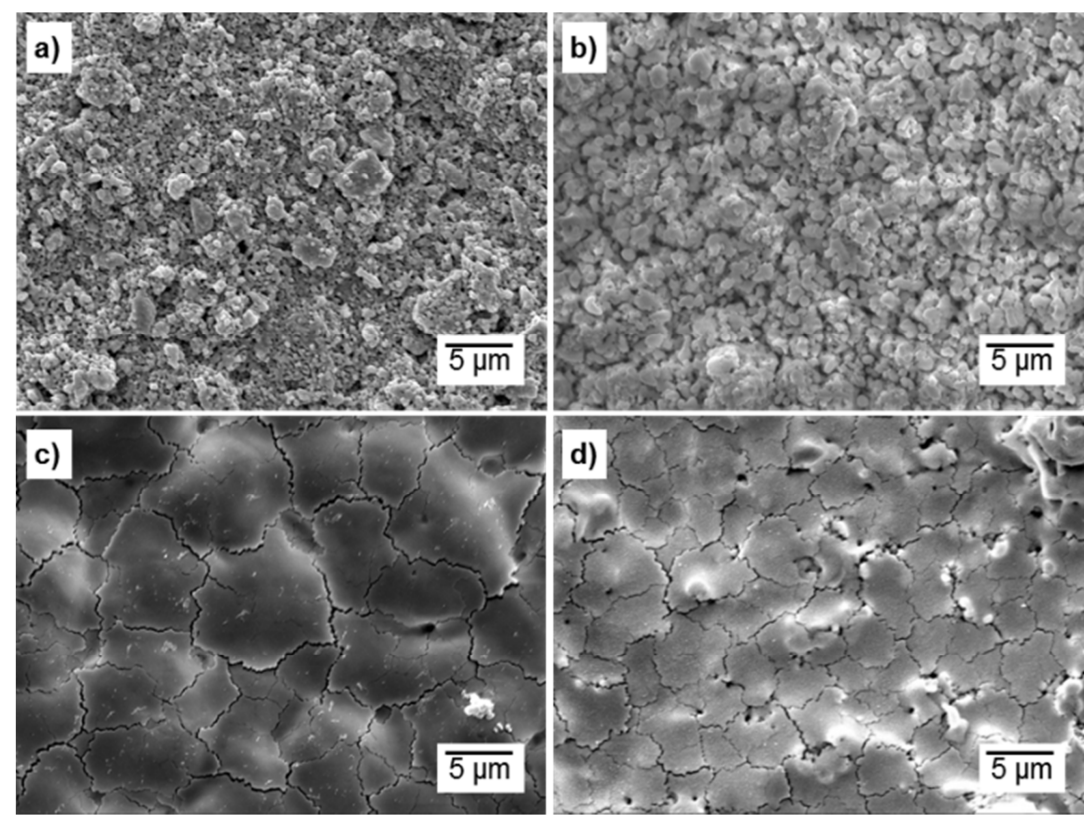

Fig. 2. SEM micrographs of CGO surface annealed at $1200^{\circ} \mathrm{C}$ : a) without laser treatment, b) treated by UV laser at $0.2 \mathrm{~J} \mathrm{~cm}^{-2}$ and 6000 pulses, c) treated by UV laser at $1.3 \mathrm{~J} \mathrm{~cm}^{-2}$ and 10 pulses, d) cell treated by IR laser at $3.5 \mathrm{~J} \mathrm{~cm}^{-2}$ and 10 pulses.

Table 1.

Summary of the laser processed samples.

\begin{tabular}{llll}
\hline Laser & Range of Fluence $\left(\mathrm{J} \mathrm{cm}^{-2}\right)$ & Range of number of pulses & Results \\
\hline UV & $0.05-0.3$ & $10-60$ & No effect \\
& $0.05-0.2$ & $1000-6000$ & No effect \\
& 0.3 & $3000-6000$ & Grain growth \\
& 1.3 & 10 & Densification + cracks \\
\hline IR & $2-3.6$ & $5-10$ & Densification + cracks \\
\hline
\end{tabular}

From all the processing conditions, four cells modified by laser treatment were selected in order to compare their performances as complete SC-SOFC with the attempt to confirm a laserinduced densification. The choice has been based on the densification obtained at the surface, either grain growth or densification with cracks.

Table 2.

Summary of tested cells, results of helium percentage passed through the CGO and results of resistance and ionic conductivity of electrolyte at $470{ }^{\circ} \mathrm{C}$.

\begin{tabular}{llllllll}
\hline Sample & Laser & $\begin{array}{l}\text { Fluence } \\
\left(\mathrm{J} \mathrm{cm}^{-2}\right)\end{array}$ & $\begin{array}{l}\text { Number } \\
\text { of pulses }\end{array}$ & Laser modification & $\begin{array}{l}\text { Helium } \\
\%\end{array}$ & $\begin{array}{l}\text { Resistance } \\
(\Omega)\end{array}$ & $\begin{array}{l}\text { lonic } \\
\text { conductivity } \\
\left(\mathrm{S} \mathrm{cm}^{-1}\right)\end{array}$ \\
\hline 1 & Reference & - & - & - & 1.10 & 14353 & $1.19 \times 10^{-3}$ \\
2 & IR & 3.5 & 10 & Densification + cracks & 1.08 & 8531 & $2.07 \times 10^{-3}$ \\
3 & IR & 2.5 & 5 & Densification + cracks & 1.07 & 7411 & $2.30 \times 10^{-3}$ \\
4 & UV & 1.3 & 10 & Densification + cracks & 0.76 & 11951 & $1.43 \times 10^{-3}$ \\
5 & UV & 0.2 & 6000 & Grain growth & 0.65 & 12381 & $1.38 \times 10^{-3}$ \\
\hline
\end{tabular}




\subsection{Permeation tests}

In order to evaluate the diffusion of gases through the modified surface of the electrolyte, permeation test were carried out on the selected samples and results are reported in Table 2.

The helium percentage that crossed the layer of electrolyte was lower for the samples treated by the UV laser, especially for the one which presented grain growth (sample 5). A slight decrease of helium permeation was also observed for the cell with a densified but cracked layer (sample 4). The UV laser treatment allows unambiguously to reduce the helium diffusion through the CGO electrolyte. On the other hand, the cells treated with the IR laser show similar helium diffusion as the cell without the laser treatment. In that case, the cracks seem to generate similar or larger porosity relative to the initial electrolyte porosity and not allow the formation of the diffusion barrier layer.

Besides a good densification of the electrolyte, SC-SOFC requires also a low resistance of the electrolyte. This was further evaluated by electrical conductivity measurements.

\subsection{Electrical characterizations}

By measuring the electrical conductivity of the electrolyte layer, it was possible to evaluate the laser-induced modifications. Fig. 3 shows Nyquist impedance diagrams at $470{ }^{\circ} \mathrm{C}$ of the sample 3 treated by IR laser and the reference without laser treatment. Others samples treated by laser presented similar behavior as sample 3. The high frequency response is generated from the electrolyte layer (bulk and grain boundary contributions) and the low frequency response results from electrodes contribution. Relative to reference sample without laser treatment, it is observed that laser treatment generates changes in the electrical behavior of the samples. It indicates that the interactions between the modified electrolyte surfaces and the electrodes are different.

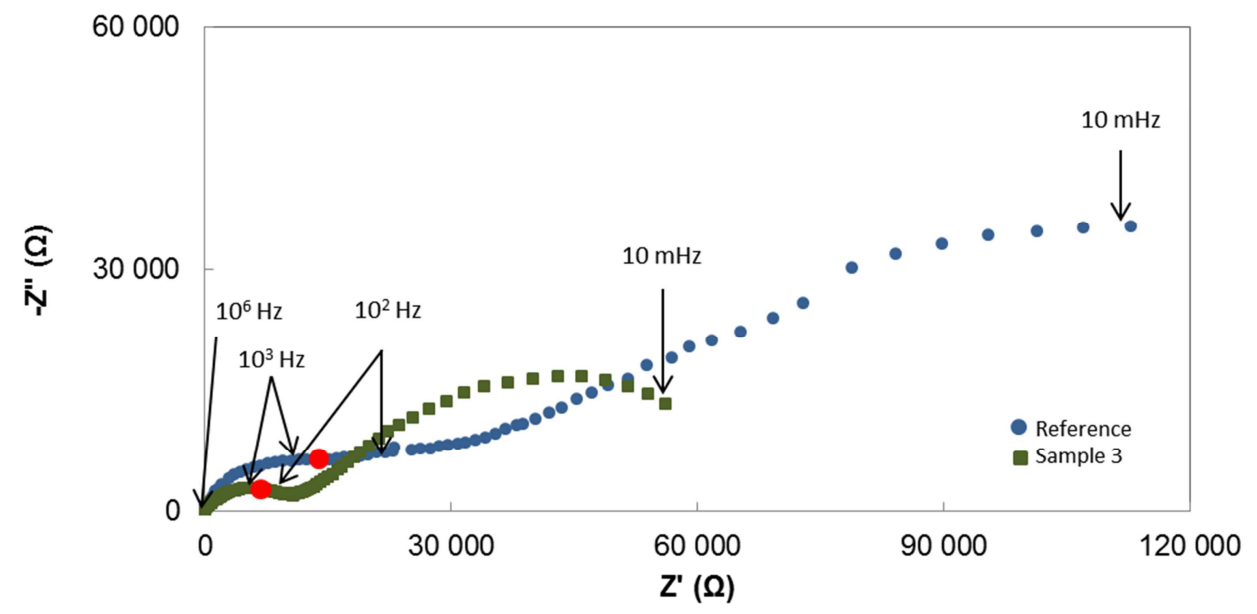

Fig. 3. Nyquist diagrams obtained at $470{ }^{\circ} \mathrm{C}$ for sample 3 and reference without laser treatment. Electrolyte resistance was measured at $500 \mathrm{~Hz}$ (red points). 
Resistance values of the electrolyte determined from the impedance diagram at high frequency range $(1 \mathrm{MHz}-500 \mathrm{~Hz})$ measured at $470{ }^{\circ} \mathrm{C}$ are presented in Table 2. From these resistances, ionic conductivities $(\sigma)$ were also calculated in order to compare these results without the effect of the shape contribution of the co-planar electrodes configuration. Ionic conductivity is reported in table 2 and was determined by:

$$
\sigma=\frac{1}{\mathrm{Rxf}}
$$

where $R$ is the electrolyte resistance (in $\Omega$ ) and $f$ is a shape factor (in $\mathrm{cm}$ ) relative to the coplanar-symmetrical electrode configurations calculated from the work of Rembelski et al. [3]. The calculated value of the shape factor is about $0.0585 \mathrm{~cm}$.

Results in Table 2 show that the resistances of the samples treated by the laser were lower than the resistance of the reference sample without the laser treatment. A cell with lower resistance should induce better electrical performances. Densified but cracked surface leaded to lower resistance than cell with grain growth, showing a different interaction between the treated surface of the electrolyte and the electrodes for these two laser modifications. The best results were observed for the cells treated by IR laser. However, one can see that the ionic conductivity is lower than values reported in the literature, around $9.5 \times 10^{-3} \mathrm{~S} \mathrm{~cm}^{-1}$ at $500^{\circ} \mathrm{C}$ [22]. Laser treatments provide an increase of electrolyte layer conductivity compared to the reference; however it can further be improved.

\subsection{Characterization of fuel cells}

Complete SC-SOFC performances characterization was carried out on cells described in Table 2. The measurements were performed, in a methane-oxygen mixture, in the range $400{ }^{\circ} \mathrm{C}$ to 600 ${ }^{\circ} \mathrm{C}$ with step of $50{ }^{\circ} \mathrm{C}$. Figure 4 shows the polarization curves at $450{ }^{\circ} \mathrm{C}$ for a cell treated by UV laser which presented grain growth and a reference cell without laser treatment. The best results are obtained $\mathrm{R}_{\text {mix }}=\mathrm{CH}_{4} / \mathrm{O}_{2}=0.67$ at $450^{\circ} \mathrm{C}$. Concerning $\mathrm{OCV}$, an increase of values is visible in the cell treated by the laser, notably for the experiment at $R_{\text {mix }}=0.67$, from $0.37 \mathrm{~V}$ to $0.44 \mathrm{~V}$. Performances improvements were more evident looking at the power density where the power density of the cell with laser treatment $\left(21.1 \mathrm{~W} \mathrm{~cm}^{-2}\right)$ is twice the value of the cell without laser treatment $\left(11.3 \mathrm{~W} \mathrm{~cm}^{-2}\right)$ also for the test with $R_{\text {mix }}=0.67$. These results can be explained by the fact that grains growth provides a denser surface, thus decreasing the hydrogen diffusion from the anode to the cathode, as observed in permeation tests. Indeed, for a porous electrolyte, diffusion of hydrogen through the electrolyte pores can occur; the oxygen partial pressure at the cathode side is lower and that decreases the OCV and then the performances, according to Suzuki et al. [2]. Better results were obtained with $R_{\text {mix }}=0.67$, compared to $R_{\text {mix }}=2$, because less methane is flowed and as a consequence less hydrogen is produced compared to higher $\mathrm{R}_{\text {mix }}[3]$.

Concerning cells with a densified but cracked electrolyte, treated by UV or IR lasers, OCV and maximum power densities were equivalent or lower than cell without laser treatment. 


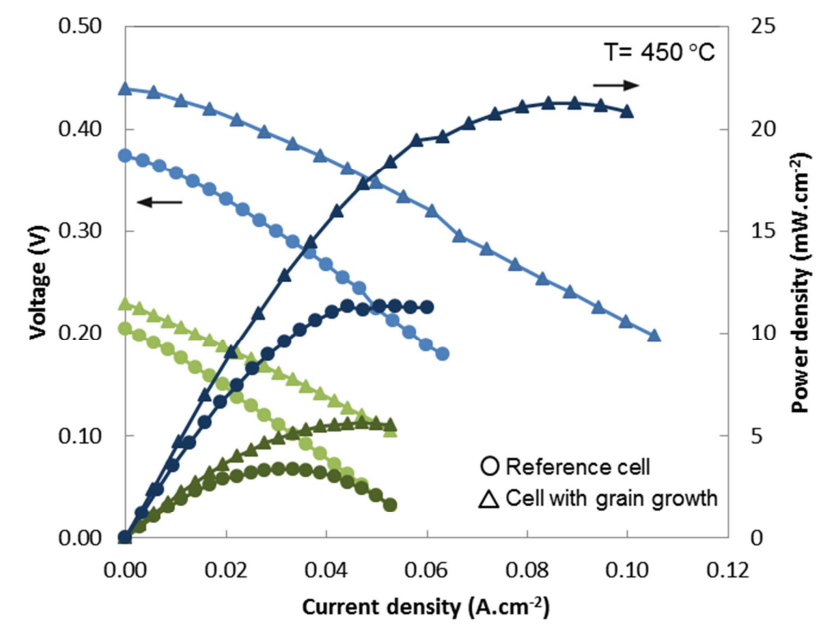

Fig. 4. Polarization curves of the reference cell and the cell treated with UV laser at a laser fluence of $0.2 \mathrm{~J} \mathrm{~cm}^{-2}$ with 6000 laser pulses which presented grain growth on the surface (sample 5) operated in $R_{\text {mix }}=2$ (green curves) and $R_{\text {mix }}=0.67$ (blue curves) at $450^{\circ} \mathrm{C}$.

\subsection{Discussion}

Diffusion through the electrolyte and its resistance are two important parameters in SC-SOFC. Indeed diffusion affects the value of the OCV, then OCV and electrolyte resistance influence the performances. As shown previously, UV laser treated cells, especially in the range of low laser fluence and high number of pulses, leads to the lowest helium diffusion. On the other hand, IR laser treated cells leads to the lowest electrolyte resistance. Finally, the best results in the characterization of complete cells were obtained by the cell with grain growth on electrolyte surface (UV laser treated cell).

In this case, percentages of diffused helium through CGO layer were lower than cells with densified cracked surface. Indeed cracks may have the same effect as a porous electrolyte and allow hydrogen diffusion between the anode and the cathode, decreasing the OCV and thus dropping cells performances [2,3]. Decrease of gas permeation has a higher effect on improvement of cells performances than the decrease of electrolyte resistance. Similar effect was reported by Rembelski et al. [3] where a cell with a thicker electrolyte presented better performances than a cell with a thin electrolyte. Higher thickness increases electrolyte resistance but decreases hydrogen diffusion. Then performances drop due to electrolyte thickness are compensated by hydrogen diffusion limitation and highest values of OCV.

\section{Conclusion}

CGO electrolyte surfaces of SC-SOFC were densified using UV and IR lasers to limit hydrogen diffusion from the anode to the cathode. The surface modifications were confirmed by scanning electron microscopy showing grain growth or densified cracked electrolyte surface. Permeation tests showed $41 \%$ decrease of helium diffusion through CGO for the cell with grain growth and $31 \%$ for the cell densified but cracked treated by UV laser. Densified cells by IR laser presented similar results to cell without laser treatment concerning helium permeation tests. Higher electrical conductivity were obtained for laser treated cells, mainly for IR laser annealed cells 
where the values of electrical conductivity were almost two times higher than the results for the cell without laser treatment. As for SC-SOFC characterizations, cell treated by UV laser that presented grain growth showed better SC-SOFC performances at $450^{\circ} \mathrm{C}$, particularly an increase of power density $\left(21.1 \mathrm{~mW} \mathrm{~cm}^{-2}\right)$ relative to a cell without laser treatment $(11.3 \mathrm{~mW} \mathrm{~cm}$ ${ }^{2}$ ). Performances of others laser treated cells were not improved compared to reference cell. Densification of the electrolyte with cracks was not sufficient. This confirms the need of a diffusion barrier layer for these systems. We showed that by the control of laser treatment parameters (laser wavelength, fluence, number of pulses) it was possible to reach this objective.

\section{Acknowledgements}

This work was supported by the LABEX MANUTECH-SISE (ANR-10-LABX-0075) of Université de Lyon, within the program "Investissements d'Avenir" (ANR-11-IDEX-0007) operated by the French National Research Agency (ANR). This work was also performed within the framework of the EQUIPEX MANUTECH-USD (ANR-10-EQPX-36-01) operated by the French National Research Agency (ANR).

\section{References}

[1] M. Kuhn, T.W. Napporn, Single-Chamber Solid Oxide Fuel Cell Technology - From its Origins to Today's State of the Art, Energies. 3 (2010) 57-134.

[2] T. Suzuki, P. Jasinski, V. Petrovsky, H.U. Anderson, F. Dogan, Performance of a Porous Electrolyte in Single-Chamber SOFCs, J. Electrochem. Soc. 152 (2005) A527.

[3] D. Rembelski, M. Rieu, L. Combemale, J.P. Viricelle, In situ reduction and evaluation of anode supported single chamber solid oxide fuel cells, J. Power Sources. 242 (2013) 811-816.

[4] J.-P. Viricelle, S. Udroiu, G. Gadacz, M. Pijolat, C. Pijolat, Development of Single Chamber Solid Oxide Fuel Cells (SCFC), Fuel Cells. 10 (2010) 683-692.

[5] M. Morales, S. Piñol, M. Segarra, Intermediate temperature single-chamber methane fed SOFC based on Gd doped ceria electrolyte and La0.5Sr0.5CoO3- $\delta$ as cathode, J. Power Sources. 194 (2009) 961-966.

[6] M.G. Chourashiya, S.H. Pawar, L.D. Jadhav, Synthesis and characterization of Gd0.1Ce0.901.95 thin films by spray pyrolysis technique, Appl. Surf. Sci. 254 (2008) 3431-3435.

[7] C. Kleinlogel, L.J. Gauckler, Sintering and properties of nanosized ceria solid solutions, Solid State lonics. 135 (2000) 567-573.

[8] J. Van herle, T. Horita, T. Kawada, N. Sakai, H. Yokokawa, M. Dokiya, Low temperature fabrication of (Y, Gd, Sm)-doped ceria electrolyte, Solid State lonics. 86-88 (1996) 12551258. 
[9] J. Ma, T.S. Zhang, L.B. Kong, P. Hing, S.H. Chan, Ce0.8Gd0.2O2- $\delta$ ceramics derived from commercial submicron-sized $\mathrm{CeO} 2$ and $\mathrm{Gd} 2 \mathrm{O} 3$ powders for use as electrolytes in solid oxide fuel cells, J. Power Sources. 132 (2004) 71-76.

[10] Y. Wu, K.L. Choy, L.L. Hench, Laser densification of TiO2 films prepared by aerosol assisted vapour deposition, Appl. Surf. Sci. 247 (2005) 378-383.

[11] B. Qian, Z. Shen, Laser sintering of ceramics, J. Asian Ceram. Soc. 1 (2013) 315-321.

[12] A. Bacciochini, N. Glandut, P. Lefort, Surface densification of porous ZrC by a laser process, J. Eur. Ceram. Soc. 29 (2009) 1507-1511.

[13] V. Liberman, M. Rothschild, J.H.C. Sedlacek, R.S. Uttaro, a. Grenville, Excimer-laserinduced densification of fused silica: Laser-fluence and material-grade effects on the scaling law, J. Non. Cryst. Solids. 244 (1999) 159-171.

[14] D. Triantafyllidis, L. Li, F.H. Stott, Crack-free densification of ceramics by laser surface treatment, Surf. Coatings Technol. 201 (2006) 3163-3173.

[15] Q. Lonné, N. Glandut, P. Lefort, Surface densification of porous ZrB 2-39mol.\% SiC ceramic composites by a laser process, J. Eur. Ceram. Soc. 32 (2012) 955-963.

[16] P. Bertrand, F. Bayle, C. Combe, P. Goeuriot, I. Smurov, Ceramic components manufacturing by selective laser sintering, Appl. Surf. Sci. 254 (2007) 989-992.

[17] C.S. Sandu, V.S. Teodorescu, C. Ghica, B. Canut, M.G. Blanchin, J. a. Roger, et al., Densification and crystallization of $\mathrm{SnO} 2 \mathrm{Sb}$ sol-gel films using excimer laser annealing, Appl. Surf. Sci. 208-209 (2003) 382-387.

[18] E.D. Tsagarakis, C. Lew, M.O. Thompson, E.P. Giannelis, Nanocrystalline barium titanate films on flexible plastic substrates via pulsed laser annealing, Appl. Phys. Lett. 89 (2006) 23-25.

[19] L. Bradley, L. Li, F.. Stott, Characteristics of the microstructures of alumina-based refractory materials treated with CO2 and diode lasers, Appl. Surf. Sci. 138-139 (1999) 233-239.

[20] D. Bäuter, Laser Processing and Chemistry, Third, Springer, 2000.

[21] L. Bradley, L. Li, F. Stott, Flame-assisted laser surface treatment of refractory materials for crack-free densification, Mater. Sci. Eng. A. 278 (2000) 204-212.

[22] B.C.. Steele, Appraisal of Ce1-yGdyO2-y/2 electrolytes for IT-SOFC operation at $500^{\circ} \mathrm{C}$, Solid State Ionics. 129 (2000) 95-110. 